\title{
EXERGAMES IN ADOLESCENTS: ASSOCIATED FACTORS AND POSSIBLE REDUCTION IN SEDENTARY TIME
}

Uso de exergames em adolescentes: fatores associados e possibilidade de redução do tempo sedentário

\author{
Iazana Garcia Custódioa,* (1), Adriano Akira Ferreira Hinob (D), \\ Cristiano Copetti Rodriguez ${ }^{a}\left(\mathbb{D}\right.$, Edina Maria de Camargo ${ }^{c}$ (D), Rodrigo Siqueira Reis ${ }^{d}$
}

\section{ABSTRACT}

Objective: To describe the use of exergames, associated factors and to quantify the time attributed to the use of exergames within the time spent on video games in a sample of adolescents from Curitiba, Paraná, Brazil.

Methods: This was a cross-sectional study that evaluated frequency and weekly volume of physical activities using the Physical Activity Questionnaire for Adolescents. Weekly frequency and daily time of use of exergames and videogames were self-reported. MannWhitney and Kruskal Wallis tests were used to compare the time spent playing exergames, and Poisson regression was used to test the associations $(p<0.05)$.

Results: 495 adolescents were interviewed (51.3\% girls), predominantly aged between 12 and 13 years (41.3\%), under/ normal weight (60.4\%), medium socioeconomic status (39.8\%) and from public schools (69.3\%). Most of the participants did not have video games in their bedroom (74.3\%) and did not reach recommended levels of physical activity (55.5\%). One in five adolescents used exergames (16.4\%). Age (RP: $0.54 ; 95 \% \mathrm{Cl} 0.30-0.97, \mathrm{p}=0.039)$ and having a console in the bedroom (RP: $1.89 ; 95 \% \mathrm{Cl} 1.27-2.81, \mathrm{p}=0.002$ ) were associated with exergame use. Male sex ( $\bar{X}: 195.0 ; A I Q: 486.3 ; p=0.024)$ practice of leisure time physical activity ( $\bar{X}: 160.0$; AIQ: 350.0; $p=0.048$ ) were associated with weekly volume of exergame use. Conclusions: Overall, less than two out of ten adolescents used exergames, and the use was higher among young adolescents and those who had a console in their bedrooms. Volume of use was higher among boys and those performing more than five hours of leisure time physical activity per

\section{RESUMO}

Objetivo: Descrever o uso de exergames, os fatores associados e quantificar o tempo atribuído ao uso de exergames dentro do tempo total de uso de videogames em uma amostra de adolescentes de Curitiba, Paraná.

Métodos: Estudo com delineamento transversal no qual a frequência e o volume semanal de atividades físicas foram avaliados com o Questionário de Atividade Física para Adolescentes. A frequência semanal e o tempo diário de uso de exergames e de videogames foram autorreportados. Os testes $U$ de Mann-Whitney e Kruskal-Wallis compararam o tempo de uso dos exergames; e a regressão de Poisson, as associações $(p<0,05)$.

Resultados: Foram entrevistados 495 adolescentes (51,3\% meninas), predominantemente com idade entre 12 e 13 anos (41,3\%), baixo peso/normal (60,4\%), nível socioeconômico médio $(39,8 \%)$ e de escolas públicas (69,3\%). A maioria não possuía videogame no quarto (74,3\%) e não cumpria a recomendação de atividade física (55,5\%). Um em cada cinco adolescentes usava exergames (16,4\%). A idade (razão de prevalência [RP] 0,54; intervalo de confiança de $95 \%$ [IC95\%] 0,30-0,97; $p=0,039$ ) e a posse de videogames no quarto (RP 1,89; IC95\% 1,27-2,81; $p=0,002$ ) foram associadas com o uso. Ainda, o sexo masculino ( $\bar{X}: 195,0 ; A I Q: 486,3 ; p=0,024)$ e a prática de atividade física no lazer ( $\bar{X}: 160,0 ; A I Q: 350,0 ; p=0,048)$ apresentaram associação com o volume semanal.

Conclusões: Ao todo, menos de dois em cada dez adolescentes utilizam exergames, sendo a frequência maior entre os mais novos e que possuem consoles de jogos nos quartos. O volume de uso é maior entre os meninos e entre adolescentes que praticam mais do que cinco horas de atividades físicas de lazer na semana.

*Corresponding author. E-mail: iazanacustodio@gmail.com (I. G. Custódio).

a Universidade Tecnológica Federal do Paraná, Curitiba, PR, Brazil.

bontifícia Universidade Católica do Paraná, Curitiba, PR, Brazil.

'Universidade Federal do Paraná, Curitiba, PR, Brazil.

'Washington University in St. Louis, Brown School, Saint Louis, Missouri, United States of America.

Received on January 07, 2018; Approved on May 26, 2018; available online on October 03, 2019. 
week. In addition, a considerable part of the time devoted to the use of video games, was in fact, destined to the use of exergames.

Keywords: Motor activity; Video games; Adolescent behavior.
Além disso, parte considerável do tempo destinado ao uso de videogames foi, na realidade, destinada ao uso de exergames.

Palavras-chave: Atividade motora; Jogos de vídeo; Comportamento do adolescente.

\section{INTRODUCTION}

Several factors have contributed to the reduction of physical exercise among young people. Among these factors are the growing process of urbanization, the reduction of public spaces for physical activity, the increase in violence, the technological dependence (when the individual cannot control their own use of the internet / games / cell phones) and the various facilities gained from modernization. ${ }^{1,2}$ In view of these changes, there is a transition from predominantly outdoor physical activities to those performed indoors, which appear to be safer, but may lead to a more sedentary lifestyle. ${ }^{3,4}$ Data presented by the National School Health Survey (PeNSE) indicate that more than half of ninth graders spend three hours or more on an average weekday on sedentary activities such as watching television, using a computer, playing video games or doing other activities while sitting down. ${ }^{5}$

In this context, the growing interest in video games in the adolescent population is perceived as one of the leisure activities in this age group. ${ }^{6}$ However, while traditional video games are classified as sedentary activity, ${ }^{6-8}$ active or exergames stimulate movement through motion sensors. ${ }^{9.10}$ This feature has made exergames one of the alternatives for increasing physical activity levels among young people, ${ }^{11}$ in addition to their potential for developing cognitive, motor and spatial orientation skills. ${ }^{12-14}$

Despite the increased use of exergames, most of the questionnaires for assessing sedentary behavior only measure screen time, which may include the time adolescents spend on exergames. ${ }^{15,16}$ This approach may result in misclassification, and may overestimate the time spent on sedentary activities if the time in exergames is not discriminated. A study on young Australians, found that $42 \%$ of teenagers who play video games also use exergames. The authors found that $20 \%$ of the total time adolescents reported playing video games was spent playing exergames, indicating that approximately one fifth of sedentary behavior in relation to time, was being misclassified. ${ }^{17}$

Although there are already a considerable number of studies on the use of exergames, ${ }^{11,18}$ most studies have aimed to evaluate the effects of exergames on several outcomes. ${ }^{19,20}$ Still, descriptive studies on the use of this new technology are, in their entirety, from countries with a different socioeconomic context, which may not represent the Brazilian reality. Thus, investigating this new alternative of physical activity may represent a breakthrough in studies on sedentary behavior, since few studies have explored this possibility. Therefore, the objective of this study was to describe the use of exergames and the factors associated with their use, as well as to verify the time spent playing exergames within the total time of video game use in a sample of adolescents from Curitiba, Paraná.

\section{METHOD}

The data used in this study is part of the International Physical Activity and Environment Network (IPEN) project, a multicenter study conducted in 19 countries. The study has a cross-sectional design, conducted with a household survey and face-to-face interviews. All participants - guardians and adolescents - signed an informed consent form, and the study was approved by the Research Ethics Committee of Pontifícia Universidade Católica do Paraná(PUC-PR) (135-945 / 2012). Sampling was performed in multiple stages. Firstly, 32 census tracts within the city of Curitiba were collected, and each sector contained 15 adolescents. The 2,395 census tracts of the city were classified according to income and walkability characteristics. As an income indicator, the average household income was used, according to the Brazilian Institute of Geography and Statistics (IBGE) in 2010.

Walkability is the English term that seeks to identify areas with favorable design and characteristics for everyday walking. In the present study, this concept was operationally composed of an indicator, considering mixed land use, street connectivity, and residential and commercial densities. The sector income and walkability indicators were classified into deciles. Next, the second and third deciles were selected as those with low income and walkability, while the census tracts located in the eighth and ninth deciles were determined as those with high income and walkability. Thus, census tracts were selected from the four quadrants resulting from the combination of income extremes and walkability. Finally, eight census tracts 
from each quadrant were selected: high income and low walkability; low income and low walkability; low income and high walkability; and high income and high walkability, totaling 32 census tracts. ${ }^{22}$ The quadrants contained in these sectors were considered and the listing process was performed in all quadrants and households. The researchers addressed all households within the sector and, when they found a household where residents met the eligibility criteria, they invited them to participate in the project.

The study included adolescents between 12 and 17 years of age. Adolescents who lived less than a year in the neighborhood or who had any physical and / or cognitive limitations that prevented the practice of physical activity were not considered eligible. The final study sample consisted of 495 adolescents. The calculation of the power performed a posteriori, considering an alpha of 0.05 , an association strength of 1.7 and a prevalence of outcome of $16 \%$, allows the identification of associations with a power of 0.75 .

Twenty-three interviewers, including undergraduate and postgraduate students, conducted face-to-face interviews after receiving 12-hour theoretical-practical training on how to conduct the approach at home and with participants, selection criteria, conduction of interviews, filling out forms and identifying the refusal rate. Data collection was performed between August 2013 and May 2014.

Physical activity performed by adolescents was assessed using the Adolescent Physical Activity Questionnaire (QAFA). ${ }^{23}$ This questionnaire was first developed in checklist format for North American adolescents, ${ }^{24}$ which was translated and adapted for Brazilian adolescents. ${ }^{23}$ The questionnaire consists of a list of 24 moderate to vigorous physical activities, with the possibility for adolescents to add activities beyond those listed. The questionnaire showed good reproducibility (ICC $=0.88 ; 95 \%$ CI $0.84-0.91$ ) and concurrent validity when compared with a 24 -hour recall $(r=0.62$; $\mathrm{p}<0.001){ }^{23}$ The level of leisure time physical activity was calculated from the sum of the weekly time in each of the listed activities. Regarding analysis, the variable was categorized as "up to 419 minutes per week" and " 420 minutes per week or more" according to the physical activity recommendations for adolescents. ${ }^{25,26}$

The use of exergames was assessed by the question "Consider the activities you perform outside of school. In a normal week, do you play active games (Xbox, Wii, etc.)? ", The possible answers were" Yes "or" No". If the answer was yes, the weekly frequency of use (days / week) and the daily duration (minutes / day) were also questioned. Through these two variables it was possible to calculate the weekly volume of use (minutes / week).
Video game ownership was assessed with the following question: "Indicate if you have these items in your room. Video games (Xbox, Playstation, Nintendo Wii)", with "Yes" and "No" being the possible answers. Video game usage time was also measured with the question "How long do you play video games on your device or computer on a normal school day?", With the possible answers being "None", "15 minutes / day" , "30 minutes / day", "1 hour / day", "2 hours / day", "3 hours / day" and "4 hours or more / day".

The adolescent's sex was recorded by the interviewer and the age was obtained based on the date of birth and the date of the interview, and classified into three age groups ("1213 years", "14-15 years" and " $16-17$ years"). Body mass and height were measured using a digital scale and a stadiometer which was used to calculate body mass index (BMI), and then categorized into four levels ("underweight"; "normal weight"; "overweight"). "and "obesity") ${ }^{27}$. Socioeconomic status (NSE) was assessed using a standardized questionnaire based on ownership of property at home, education of the financial head of the household, and the presence of domestic workers. ${ }^{28}$ For analysis purposes, the NSE was classified into three levels: "high" (classes A1 + A2), "medium" (classes B1 + B2) and "low" (classes $\mathrm{C} 1+\mathrm{C} 2+\mathrm{D}+\mathrm{E})$. The schooling of the guardian was put into three levels: "Complete elementary school", "Complete high school" and "Complete superior level education". The adolescents reported the type of school they attended (private or public), formal work (yes or no) and grade repetition / year (never, once or twice, 3 or more).

Sample characteristics were described by absolute and relative frequency distribution. The normality of variables with continuous measurement scale (time of use of exergames) was verified using the Kolmogorov-Smirnov test. The data did not present normal distribution, thus, for description, we used, in addition to the mean and standard deviation, the median and interquartile range. The Mann-Whitney and Kruskal-Wallis U-tests were performed in order to compare the duration of use of exergames, according to sociodemographic variables, possession of video games in the bedroom and the level of leisure time physical activity. The comparison between the proportions was performed using the chisquare test. Poisson regression was used to test the association between the use of exergames and sociodemographic variables, the fact of having video games in the bedroom and the level of leisure time physical activity. Descriptive statistics measured the time spent playing video games and how much of this time was attributed to exergames. All analyzes were performed using SPSS 20.0 software, and the significance level was maintained at $5 \%$. 


\section{RESULTS}

Among the 495 adolescents (51.3\% girls) included in the final sample (Table 1), there was a higher proportion of adolescents aged 12 and 13 years (41.3\%), nutritional status classified as underweight / normal weight (60.4\%).), an average NSE (52.9\%) and parents or guardians with complete high school (39.8\%). Most respondents studied in a public school $(69.3 \%)$, never repeated $(70.5 \%)$, did not work $(91.1 \%)$ and did not have video games in their room $(74.3 \%)$.

Approximately half of the participants (55.5\%) practiced some type of leisure time physical activity e (Table 1), and less than two out of five used exergames (16.4\%). Among those who used exergames, weekly use was $3.0 \pm 2.2$ days / week ( $\min .:$ 1; max: 7; median: 2.0) for $97.5 \pm 84.1$ minutes / day ( min: 10; max: 420; median: 60.0), with a weekly amount (days / week $^{*}$ minutes / day) of $373.3 \pm 542.7$ minutes / week (min: 10; max: 2100 median: 120.0).

The use of exergames (Table 2) was only higher for boys ( $\mathrm{p}=0.024$ ) and for those who did $420 \mathrm{~min} / \mathrm{wk}$. or more physical activity during their leisure time $(\mathrm{p}=0.048)$.

Table 3 presents the bivariate associations on the use of exergames with sociodemographic, health and physical activity variables. Age and video game ownership in the bedroom were the only variables associated with the use of exergames. Adolescents 16 and 17-year-old adolescents old have $46 \%$ lower prevalence of using exergames compared to 12-and 13-yearold adolescents $(\mathrm{p}=0.039)$. Those who had video games in the bedroom had $89 \%$ more prevalence of use when compared to those who did not $(\mathrm{p}=0.002)$.

Graph 1 shows the video game usage time (minutes / day) attributed to the use of exergames (minutes / day). Exergame usage volumes exceeded more than half of total video game usage time in almost all usage categories, with the exception of 2 hours / day.

\section{DISCUSSION}

Understanding the aspects related to the use of exergames and their relationship with the total time of video game use may allow a better understanding of the sedentary behavior of adolescents. The present study identified that less than two out of ten adolescents use exergames, and that the frequency of use is higher among younger adolescents and among those who have video games in their bedroom. Among those who use exergames, the use is approximately five and a half hours per week, and is higher among boys and those who practice more than seven hours of leisure time physical activity. In addition, a considerable part of the
Table 1 Description of demographic characteristics, education and physical activity practice of study participants, Curitiba, Brazil $(n=495)$.

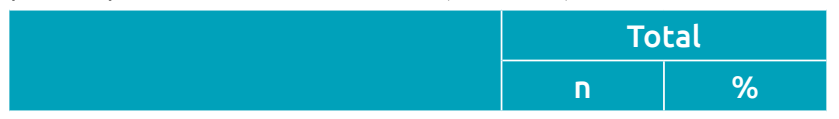

Sex

\begin{tabular}{|c|c|c|}
\hline Male & 241 & 48.7 \\
\hline Female & 254 & 51.3 \\
\hline \multicolumn{3}{|l|}{ Age (years) } \\
\hline 12 and 13 & 204 & 41.2 \\
\hline 14 and 15 & 167 & 33.7 \\
\hline 16 and 17 & 124 & 25.1 \\
\hline \multicolumn{3}{|l|}{ BMI } \\
\hline Underweight+normal weight & 299 & 60.4 \\
\hline Overweight & 142 & 28.7 \\
\hline Obese & 54 & 10.9 \\
\hline
\end{tabular}

SEL 2014

\begin{tabular}{l|c|c}
\hline $\mathrm{A} 1+\mathrm{A} 2$ & 42 & 8.5 \\
\hline $\mathrm{B} 1+\mathrm{B} 2$ & 262 & 52.9 \\
\hline $\mathrm{C} 1+\mathrm{C} 2+\mathrm{D}+\mathrm{E}$ & 191 & 38.6
\end{tabular}

Guardian's schooling

\begin{tabular}{l|c|c}
\hline Illiterate + 4th Grade & 84 & 17.0 \\
\hline Complete primary school & 72 & 14.5 \\
\hline Complete high school & 197 & 39.8 \\
\hline Higher level education complete & 142 & 28.7 \\
\hline
\end{tabular}

School

\begin{tabular}{|l|l|l}
\hline Private & 152 & 30.7 \\
\hline Public & 343 & 69.3 \\
\hline
\end{tabular}

Repeated one year

\begin{tabular}{l|c|c}
\hline Never & 349 & 70.5 \\
\hline 1 time & 100 & 20.2 \\
\hline 2 times or more & 46 & 9.3 \\
\hline Works & \multicolumn{2}{|l}{} \\
\hline No & 451 & 91.1 \\
\hline Yes & 44 & 8.9
\end{tabular}

Has a videogames console in bedroom

\begin{tabular}{l|c|c}
\hline No & 368 & 74.3 \\
\hline Yes & 127 & 25.7 \\
\hline \multicolumn{2}{|l}{} \\
\hline Leisure time PA \\
\hline Up to 419 min/wk & 293 & 59.2 \\
\hline 420 min/wk or more & 202 & 40.8 \\
\hline Uses exergames \\
\hline No & 414 & 83.6 \\
\hline Yes & 81 & 16.4 \\
\hline
\end{tabular}

BMI: body mass index; SEL: socioeconomic level; PA: physical activity. 
Table 2 Average values and interquartile ranges according to sociodemographic, health and physical activity variables with time spent using exergames in adolescents from Curitiba, Brazil $(n=81)$.

\begin{tabular}{|c|c|c|c|}
\hline & \multicolumn{3}{|c|}{$\begin{array}{c}\text { Time spent playing } \\
\text { exergames }\end{array}$} \\
\hline & Average & IQR & p-value \\
\hline \multicolumn{4}{|l|}{ Sex } \\
\hline Male & 195.0 & 486.3 & \multirow{2}{*}{0.024} \\
\hline Female & 90.0 & 240.0 & \\
\hline \multicolumn{4}{|l|}{ Age (years) } \\
\hline 12 and 13 & 203.0 & 253.9 & \multirow{3}{*}{0.103} \\
\hline 14 and 15 & 166.0 & 246.9 & \\
\hline 16 and 17 & 122.0 & 231.7 & \\
\hline \multicolumn{4}{|l|}{ BMI } \\
\hline $\begin{array}{l}\text { Underweight+normal } \\
\text { weight }\end{array}$ & 120.0 & 240.0 & \multirow{3}{*}{0.396} \\
\hline Overweight & 120.0 & 360.0 & \\
\hline Obese & 180.0 & 1395.0 & \\
\hline \multicolumn{4}{|l|}{ SEL 2014} \\
\hline $\mathrm{A} 1+\mathrm{A} 2$ & 160.0 & 420.0 & \multirow{3}{*}{0.621} \\
\hline $\mathrm{B} 1+\mathrm{B} 2$ & 120.0 & 300.0 & \\
\hline $\mathrm{C} 1+\mathrm{C} 2+\mathrm{D}+\mathrm{E}$ & 120.0 & 280.0 & \\
\hline \multicolumn{4}{|l|}{ Guardian's schooling } \\
\hline Illiterate + 4th Grade & 165.0 & 280.0 & \multirow{4}{*}{0.762} \\
\hline Complete primary school & 120.0 & 727.5 & \\
\hline Complete high school & 112.5 & 300.0 & \\
\hline $\begin{array}{l}\text { Complete Higher-level } \\
\text { education }\end{array}$ & 155.0 & 660.0 & \\
\hline \multicolumn{4}{|l|}{ School } \\
\hline Private & 210.0 & 270.0 & \multirow{2}{*}{0.210} \\
\hline Public & 120.0 & 300.0 & \\
\hline \multicolumn{4}{|l|}{ Repeated one year } \\
\hline Never & 120.0 & 300.0 & \multirow{3}{*}{0.542} \\
\hline 1 time & 105.0 & 285.0 & \\
\hline 2 times or more & 225.0 & 465.0 & \\
\hline \multicolumn{4}{|l|}{ Works } \\
\hline No & 120.0 & 300.0 & \multirow{2}{*}{0.696} \\
\hline Yes & 240.0 & . & \\
\hline \multicolumn{4}{|c|}{ Has a video game console in the bedroom } \\
\hline No & 120.0 & 215.0 & \multirow{2}{*}{0.204} \\
\hline Yes & 210.0 & 1095.0 & \\
\hline \multicolumn{4}{|l|}{ Leisure time PA } \\
\hline Up to 419 min/wk. & 90.0 & 191.3 & \multirow{2}{*}{0.048} \\
\hline 420 min/wk. or more & 160.0 & 350.0 & \\
\hline
\end{tabular}

IQR: interquartile range; BMI: body mass index; SEL: socioeconomic level; PA: physical activity. time devoted to video games was actually devoted to the use of exergames. Thus, suggesting possible classification errors in the measurement of sedentary time when using global screen time as measurements.

The present study identified that $16.4 \%$ of adolescents reported using exergames. In a study ${ }^{21}$ conducted in 2012 in Montreal, among the 1,241 students interviewed, 24\% use exergames, i.e. almost a quarter of the total sample. Although these are differently developed countries, the difference between the proportions is 7.6 percentage points, which shows that the proportion found in this study is moving as expected, even though it is not a representative sample study.

Literature reports that the older the adolescents, the lower the use of exergames. O'Loughlin et al. ${ }^{21}$ identified $48.8 \%$ use frequency of exergames in the 14-15 age group and $23.0 \%$ among adolescents aged between 16 and 17 . Similar results were observed in Portugal in $2013,{ }^{20}$ when the use of exergames was $18.7 \%$ for 14 -year olds and $16.6 \%$ for 16-year olds. The same study reported that 18 -year old adolescents were less interested in the practice of exergames. It is speculated that available exergames are unattractive to older teenagers, since most games are dances or sports such as golf, tennis and boxing, and such activities are less common and less preferable for this age group. In addition, typical changes related to this age group such as the start of higher-level education and even entering the labor market, may influence social preferences and habits and thus diminish interest in exergames.

No significant difference in use was identified between genders, however, among the users of exergames, boys used the devices longer than girls. Bailey (2011) ${ }^{10}$ highlights that different games bring greater satisfaction for both boys and girls, but, in general, boys like them more than girls. It should be mentioned that boys are more physically active than girls, and therefore they may be more interested in exergames.

Among adolescents who reported using video games, about 40 to $80 \%$ of the time is directed to the use of exergames. Among those who reported staying up to 1 hour playing video games, approximately $61.2 \%$ of the time was spent on exergames. Fullerton et al. ${ }^{17}$ observed that $20 \%$ of the time spent on video games was devoted to the use of exergames. In absolute terms, for every hour spent playing video games, 12 minutes would be spent on physical activity rather than sedentary behavior. These results have two important practical implications. Firstly, studies focused on sedentary behavior, specifically screen time, which do not differ from exergames and video games, are overestimating sedentary behavior values. Thus, exergames 
Table 3 Bivariate associations between sociodemographic, health and physical activity variables with the use of exergames $(n=81)$.

\begin{tabular}{|l|l|l}
\hline PR & $95 \% \mathrm{Cl}$ & P-value \\
\hline
\end{tabular}

Sex

\begin{tabular}{|c|c|c|c|c|c|}
\hline Male & 42 & 17.3 & 1 & & \\
\hline Female & 39 & 15.1 & 0.88 & $(0.59-1.31)$ & 0.533 \\
\hline \multicolumn{6}{|l|}{ Age (years) } \\
\hline 12 and 13 & 40 & 19.5 & 1 & & \\
\hline 14 and 15 & 28 & 16.7 & 0.85 & $(0.55-1.32)$ & 0.486 \\
\hline 16 and 17 & 13 & 10.6 & 0.54 & $(0.30-0.97)$ & 0.039 \\
\hline \multicolumn{6}{|l|}{ BMI } \\
\hline Underweight+normal weight & 47 & 15.5 & 1 & & \\
\hline Overweight & 25 & 17.4 & 1.12 & $(0.72-1.74)$ & 0.615 \\
\hline Obese & 9 & 16.7 & 1.06 & $(0.55-2.03)$ & 0.860 \\
\hline
\end{tabular}

SEL 2014

\begin{tabular}{l|c|c|c|c|c}
\hline$A 1+A 2$ & 11 & 26.2 & 1 & & \\
\hline$B 1+B 2$ & 43 & 16.3 & 0.62 & $(0.35-1.11)$ & 0.112 \\
\hline$C 1+C 2+D+E$ & 27 & 14.1 & 0.54 & $(0.29-1.00)$ & 0.050 \\
\hline
\end{tabular}

Schooling of the guardian

\begin{tabular}{l|c|c|c|c|c}
\hline Illiterate + 4th Grade & 8 & 9.4 & 1 & & \\
\hline Complete primary school & 13 & 18.1 & 1.89 & $(0.83-4.31)$ & 0.127 \\
\hline Complete high school & 34 & 17.1 & 1.81 & $(0.87-3.74)$ & 0.109 \\
\hline Complete Higher-level education & 26 & 18.3 & 1.92 & $(0.91-4.05)$ & 0.086 \\
\hline
\end{tabular}

School

\begin{tabular}{l|c|c|c|c|c}
\hline Private & 25 & 16.1 & 1 & & \\
\hline Public & 56 & 16.1 & 0.99 & $(0.64-1.52)$ & 0.973 \\
\hline
\end{tabular}

Repeated one year

\begin{tabular}{l|c|c|c|c|c}
\hline Never & 59 & 16.7 & 1 & & \\
\hline 1 time & 16 & 15.8 & 0.94 & $(0.57-1.56)$ & 0.831 \\
\hline 2 times or more & 6 & 12.8 & 0.77 & $(0.35-1.68)$ & 0.515 \\
\hline Works
\end{tabular}

Works

\begin{tabular}{l|c|c|c|c|c}
\hline No & 78 & 17.0 & 1 & & \\
\hline Yes & 3 & 6.8 & 0.39 & $(0.13-1.19)$ & 0.101 \\
\hline
\end{tabular}

Has a video game console in the bedroom

\begin{tabular}{l|l|l|l|l|l}
\hline No & 49 & 13.1 & 1 & & \\
\hline Yes & 32 & 24.8 & 1.89 & $(1.27-2.81)$ & 0.002 \\
\hline Leisure time in PA & 39 & 15.2 & 1 & & \\
\hline Up to 419 min/wk. & 39 & 19.1 & 1.24 & $(0.83-1.86)$ & 0.283 \\
\hline $420 \mathrm{~min} / \mathrm{wk}$. or more &
\end{tabular}

PR: prevalence ratio; 95\%Cl: 95\% confidence interval; BMI: body mass index; SEL: socioeconomic level; PA: physical activity. 


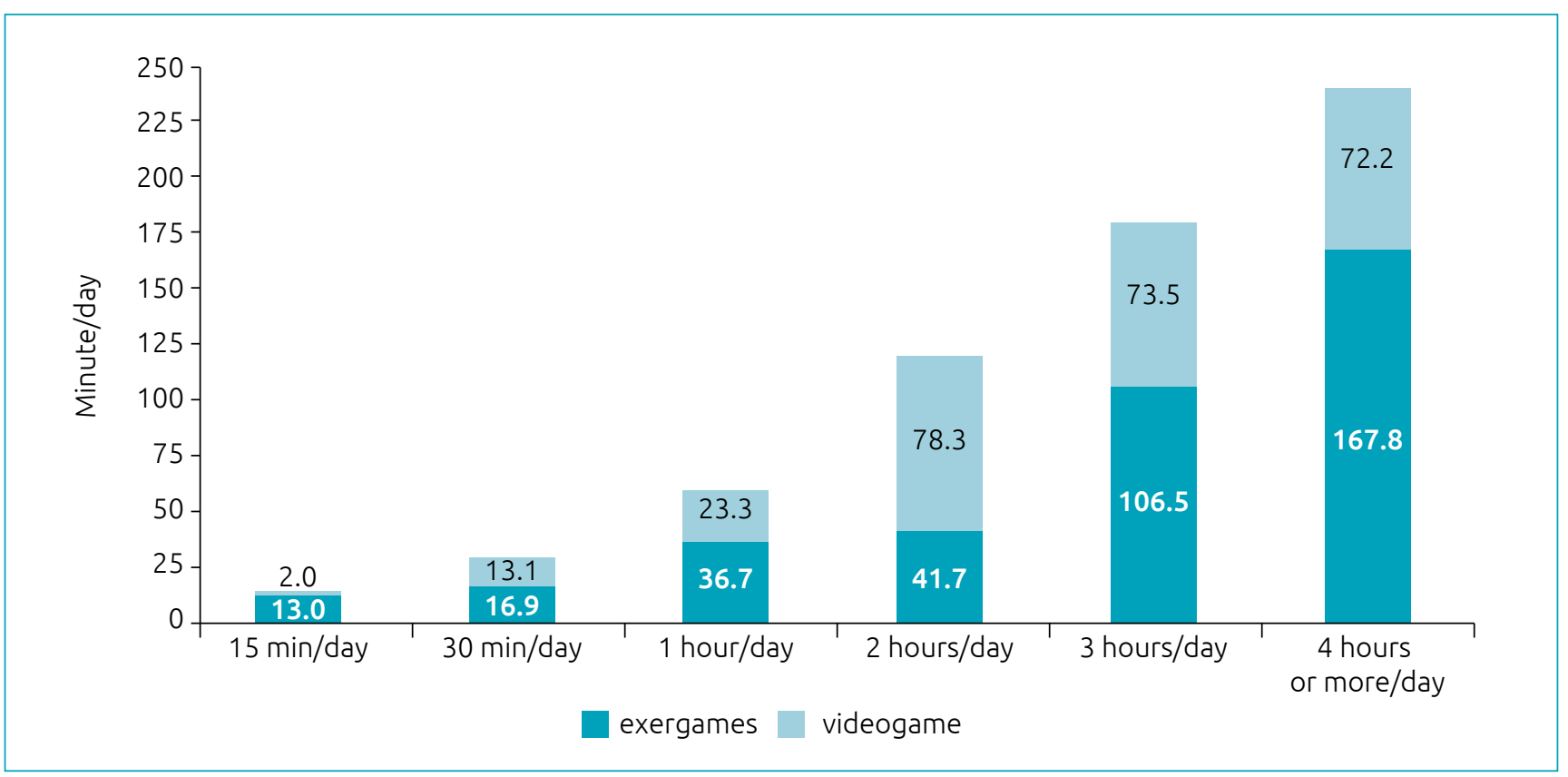

Graph 1 Average time spent on exergames (minutes / day) according to video game use categories among adolescents from Curitiba, Brazil $(n=81)$.

must be evaluated separately from traditional or non-active video games.

Secondly, the amount of time teenagers spend on using exergames can contribute to reducing sedentary behavior. For example, in the present study, among the adolescents who reported staying 240 minutes / week or more playing traditional video games, 167.8 minutes / week was spent on exergames, which would contribute to a $70 \%$ reduction in sedentary behavior. However, this logic would be applicable considering that teenagers replace the screen time of traditional video games with exergames. Thus, future studies should specifically analyze the impact that new technologies are having on adolescents' habits.

Some limitations should be considered regarding the proper interpretation and extrapolation of results. The sample is not representative of adolescents from the city, since the youths were selected from intentionally selected census tracts to allow for comparisons between walkability and income characteristics of city regions. The selection process considered the spatial and income distribution, which may somehow contribute to the approximation with the characteristics of the city's adolescents; as well as the use of questionnaires, which have limitations regarding the accuracy of the analyzed activities and possible overestimation in the reported amounts (time spent with video games). However, the questionnaires allowed us to identify the use of video games, exergames and the time dedicated to both, contributing to the understanding of sedentary behavior in adolescents.
The study results have important implications for practice, particularly for investigations related to sedentary behavior using questionnaires. Caution should be exercised in investigating sedentary behavior, as the questionnaires used only capture screen time, which may include the time adolescents spend on exergames - and as seen in the present study, should not be classified as time spent on sedentary behavior. Still, the potential that this type of game can have in relation to physical inactivity should be considered in strategies which promote physical activity.

We conclude that only $16.4 \%$ of adolescents in Curitiba use exergames. Frequency of use is higher among younger adolescents who have game consoles in their bedrooms. On the other hand, the volume of use was higher among boys and adolescents who practice more than five hours of leisure-time physical activity per week. Given the considerable proportion of adolescents who use the exergames and the time allocated for this activity, instruments that evaluate screen time as an indicator of sedentary behavior, without distinguishing use of exergames from video games, may be overestimating time spent on sedentary behavior.

\section{Funding}

National Institutes of Health, United States of America 1R01HL111378-01.

\section{Conflict of interests}

The authors declare no conflicts of interests. 


\section{REFERENCES}

1. Hulteen RM, Smith JJ, Morgan PJ, Barnett LM, Hallal C, Colyvas K, et al. Global participation in sport and leisuretime physical activities: A systematic review and metaanalysis. Prev Med. 2017;95:14-25. https://doi.org/10.1016/j. ypmed.2016.11.027

2. Silva PV, Costa Junior AL. The effects of physical activity on the health of children and adolescents. Psicol Argum. 2011;29:41-50.

3. Dias PJ, Domingos IP, Ferreira MG, Muraro AP, Sichieri R, Gonçalves-Silva RM. Prevalence and factors associated with sedentary behavior in adolescents. Rev Saude Publica. 2014;48:266-74. https://doi.org/10.1590/s00348910.2014048004635

4. Silva KS, Lopes AS, Silva FM. Comportamentos sedentários associados ao excesso de peso corporal. Rev Bras Educ Fis Esp. 2007;21:135-41.

5. Brasil. Ministério do Planejamento, Orçamento e Gestão. Instituto Brasileiro Geografia e Estatística. Pesquisa Nacional de Saúde do Escolar 2015. Rio de Janeiro: IBGE; 2016.

6. Griffiths M. Video games and health. BMJ. 2005;331:122-3. https://doi.org/10.1136/bmj.331.7509.122

7. Owen NE, Healy GN, Matthews CE, Dunstan DW. Too much sitting: the population-health science of sedentary behavior. Exerc Sport Sci Rev. 2010;38:105-13. https://doi. org/10.1097/JES.0b013e3181e373a2

8. Pate RR, O'Neill JR, Lobelo F. The evolving definition of "sedentary". Exerc Sport Sci Rev. 2008;36:173-8. https:// doi.org/10.1097/JES.0b013e3181877d1a

9. Medeiros P, Capistrano R, Zequinão MA, Silva SA, Beltrame TS, Cardoso FL. Exergames como ferramenta de aquisição e desenvolvimento de habilidades e capacidades motoras: uma revisão sistemática. Rev Paul Pediatr. 2017;35:464-71. http://dx.doi.org/10.1590/1984-0462/;2017;35;4;00013

10. Bailey BW, Mclnnis KJ. Energy Cost of Exergaming: a comparison of the energy cost of 6 forms of exergaming. Arch Pediatr Adolesc Med. 2011;165:597. https://doi. org/10.1001/archpediatrics.2011.15

11. Brito-Gomes JL, Perrier-Melo RJ, Oliveira SF, Costa M. Exergames can be tool to increase physical activity and better physical conditioning? Rev Bras Ativ Fis Saude. 2015;20:232-42. https://doi.org/10.12820/rbafs.v.20n3p232

12. Hubbard P. Evaluating computer games for language learning. Simul Gaming. 1991;22:220-3. https://doi. org/10.1177/1046878191222006

13. Li X, Atkins MS. Early childhood computer and cognitive and motor development. Pediatrics. 2004;113:1715-22. https://doi.org/10.1542/peds.113.6.1715

14. Feng J, Spence I, Pratt J. Playing an action video game reduces gender differences in spatial cognition. Psychol Sci. 2007;18:850-5. https://doi.org/10.1111/j.14679280.2007.01990.x
15. Guerra PH, Farias Jr JC, Florindo AA. Comportamento sedentário em crianças e adolescentes brasileiros: revisão sistemática. Rev Saude Publica 2016;50:9. https://doi. org/10.1590/S1518-8787.2016050006307

16. Guimarães RF, Silva MP, Legnani E, Mazzardo O, Campos W. Reproducibility of adolescent sedentary activity questionnaire (ASAQ) in Brazilian adolescents. Rev Bras Cineantropom Desempenho Hum. 2013;15:276-85. http:// dx.doi.org/10.5007/1980-0037.2013v15n3p276

17. Fullerton S, Taylor AW, Grande ED, Berry N. Measuring physical inactivity: do current measures provide an accurate view of "'sedentary'" video game time? J Obes. 2014;2014. http://dx.doi.org/10.1155/2014/287013

18. LeBlanc AG, Chaput J, McFarlane A, Colley RC, Thivel D, Biddle $\mathrm{SJ}$, et al. Active video games and health indicators in children and youth : a systematic review. PLoS One. 2013;8:e65351. https://doi.org/10.1371/journal.pone.0065351

19. Baracho AF, Gripp FJ, Lima MR. Exergames and the school physical education in the digital culture. Rev Bras Cienc Esporte. 2012;34:111-26. http://dx.doi.org/10.1590/S010132892012000100009

20. Palma N, Ramos JL. Atividade física, obesidade e videojogos ativos na escola: estudo de hábitos e práticas de jogos em jovens do ensino básico esecundário. Conferência da Sociedade Portuguesa de Ciências dos Videojogos. Videojogos, Coimbra, 2013.

21. O'Loughlin EK, Dugas EN, Sabiston CM, O'Loughlin JL. Prevalence and correlates of exergaming in youth. Pediatrics. 2012;130:806-14. https://doi.org/10.1542/peds.2012-0391

22. Alberico CO. Ambiente construído e atividade física de adolescentes: contextos baseados em geolocalização e acelerometria [master's thesis]. Curitiba (PR): UFPR; 2015.

23. Farias Junior JC, Lopes AS, Mota J, Santos MP, Ribeiro JC, Hallal PC. Validity and reproducibility of a physical activity questionnaire for adolescents: adapting the Self-Administered Physical Activity Checklist. Rev Bras Epidemiol. 2012;15:198210. http://dx.doi.org/10.1590/S1415-790X2012000100018

24. Sallis JF, Strikmiller PK, Harsha DW, Feldman HA, Ehlinger $\mathrm{S}$, Stone EJ, et al. Validation of interviewer- and selfadministered physical activity checklists for fifth grade students. Med Sci Sport Exerc. 1996;28:840-51.

25. Sociedade Brasileira de Pediatria. Grupo de Trabalho em Atividade Física. Manual de orientação-Promoção da atividade física na infância e adolescência. Rio de Janeiro: SBP; 2017.

26. World Health Organization. Global recommendations on physical activity for health. Geneva: WHO; 2011.

27. Conde WL, Monteiro CA. Body mass index cutoff points for evaluation of nutritional status in Brazilian children and adolescents. J Pediatr (Rio J). 2006;82:266-72. http:// dx.doi.org/10.2223/JPED.1502

28. Associação Brasileira de Empresas de Pesquisa. Critério de Classificação do Brasil. São Paulo: ABEP; 2014. 